\title{
The Association Between Vascular Inflammation and Depressive Disorder. Causality, Biomarkers and Targeted Treatment
}

\author{
Hans O. Kalkman \\ Retired pharmacologist, Gänsbühlgartenweg 7, CH-4132 Muttenz, Switzerland; hans.kalkman@bluewin.ch; \\ Tel.: +41-61-362-0110
}

Received: 22 April 2020; Accepted: 10 May 2020; Published: 12 May 2020

\begin{abstract}
Diabetes, obesity, atherosclerosis, and myocardial infarction are frequently co-morbid with major depressive disorder. In the current review, it is argued that vascular inflammation is a factor that is common to all disorders and that an endothelial dysfunction of the blood-brain barrier could be involved in the induction of depression symptoms. Biomarkers for vascular inflammation include a high plasma level of C-reactive protein, soluble cell-adhesion molecules, von Willebrand factor, aldosterone, and proinflammatory cytokines like interleukin- 6 or tumor necrosis factor $\alpha$. A further possible biomarker is flow-mediated dilation of the brachial artery. Treatment of vascular inflammation is expected to prevent or to reduce symptoms of depression. Several tentative treatments for this form of depression can be envisioned: eicosapentaenoic acid (EPA), valproate, Vagus-nerve stimulation, nicotinic $\alpha 7$ agonists, and agonists of the cannabinoid $\mathrm{CB}_{2}$-receptor.
\end{abstract}

Keywords: systemic low-grade inflammation; oxidative stress; geriatric depression; gender differences; leptin; EKODE; fish-oil

\section{Introduction}

Although depression is considered a disorder of the central nervous system, numerous peripheral inflammatory diseases are associated with depressive symptoms [1-6]. The presence of elevated levels of proinflammatory cytokines in blood of patients with major depressive disorder has been confirmed in multiple meta-analyses [7-9]. Therefore, the idea that inflammatory processes outside of the brain can contribute to the pathogenesis of the major depressive disorders, has gained support during recent years [10-13]. In particular, cardiovascular disorders like atherosclerosis [14], diabetes [15,16], coronary heart disease [17,18], myocardial infarction [19], or congestive heart failure [20,21] and their risk factors like tobacco smoking [22], obesity [23-25], homocysteinemia [26], or old age [27,28] involve vascular inflammation and display comorbidity with depression. For this reason, it is deemed useful to explore the causal link between vascular inflammation and depression, since it may offer information about specific biomarkers and possibilities for targeted treatment.

\section{Causes of Vascular Inflammation}

\subsection{Comorbidity Between Diabetes and Depression}

Diabetes is characterized by hyperglycemia and insulin resistance in adipose tissue [29]. Glucose metabolism in endothelial cells during hyperglycemia induces a chronic elevation of intracellular diacylglycerol, which provokes a protein kinase C-dependent production of superoxide. This reactive oxygen species promotes vascular inflammation by the activation of NFKB-mediated transcription of the adhesion molecules VCAM1 (vascular cell adhesion molecule-1) and ICAM1 (intercellular 
cell adhesion molecule-1), and the chemokines MCP1 (monocyte chemotactic protein-1) and IL8 (interleukin-8) [29]. Hyperglycemia also promotes a chemical reaction between the aldehyde-group of sugars and the amino group of amino acids [30]. These products are called 'advance glycation end products' (or 'AGE'). AGEs represent a quite complex class of covalently-modified proteins that are formed by a non-enzymatic reaction between an aldehyde (mostly from sugar) and amine groups from proteins [31]. Such reaction products exert a pathogenic role in disorders that involve an oxidative process, like diabetes or atherosclerosis [31]. AGEs exert their tissue-damaging and proinflammatory effects via activation of a receptor that is referred to as 'RAGE' and which is expressed by immune cells, endothelial cells, and vascular smooth muscle cells [30]. Activation of RAGE on endothelial cells leads to enhanced activity of NFKB and, as a consequence, transcription of adhesion molecules [30,32]. Insulin resistance in adipocytes leads to the release of free fatty acids into the circulation [29]. Free fatty acids act as toll-like receptor-4 (TLR4)-agonists and trigger NFKB-mediated production of the proinflammatory cytokines, TNF $\alpha$ and IL6 [33]. Moreover, in hepatocytes these cytokines stimulate the release of acute-phase protein, CRP (C-reactive protein), whereas TNF $\alpha$, IL6 and CRP can, in turn, provoke insulin-resistance in target cells such as the endothelium [29,34]. Hepatocytes filter the circulating free fatty acids and pack them into very-low density lipoprotein (VLDL) particles. VLDL particles, especially when containing oxidized VLDL are known to contribute to endothelial dysfunction [29]. So, diabetes activates circular processes that result in enhanced leukocyte diapedeses, platelet reactivity, mitogenesis, blood coagulation, and vasoconstriction, while endothelium-dependent vasodilatation is impeded [34]. Notably, these deleterious vascular effects also occur at the blood brain barrier (BBB). For instance, there is a significant association between diabetes on the one hand and reduced cerebral blood flow or lacunar infarcts on the other hand [35]. So, diabetes increases several factors that are associated with vascular inflammation. Large meta-analyses confirm the high comorbidity of diabetes and depression $[15,16]$.

\subsection{Comorbidity Between Female Obesity and Depression}

Overnutrition is an essential cause of insulin resistance and leads to obesity and atherosclerosis [36]. In prospective cohort studies, the association between obesity and depression was determined to be bidirectional [24,25]. Obesity rates are high in depressed patients, and conversely, the incidence of depression in obese individuals approaches a remarkable 30\% [23]. Notably, from cross-sectional studies, it seems that obesity is associated with depression in females, but this is apparently not the case for male obesity [25,37-39]. This gender difference may relate to a difference in leptin signaling. Leptin is produced by adipocytes from white fat, and over-nutrition raises the circulating levels of leptin [40]. Indeed, obese depression patients display high levels of leptin in plasma $[23,24,39]$. Reduction in body fat by means of dietary restriction provoked not only a reduction in leptin levels but in parallel also led to a reduction in depression scores [41]. But importantly, whereas high leptin levels seem to predict depression ratings in females, they did not associate with male depression [39]. It should be noted that comorbidities like hypertension, hyperlipidemia, or inflammation parameters like plasma CRP, IL6, or TNF $\alpha$ did not differ between genders [39]. Activation of leptin receptors on human abdominal perivascular adipocytes [42] or human adrenal cortex [43,44] stimulates aldosterone production. In females, visceral obesity directly correlates with plasma aldosterone levels, independently of plasma renin-levels $[43,45]$. Weight loss with a concomitant reduction of visceral adipose tissue in females led to a reduction in plasma aldosterone levels. In males, however, such an effect was not observed [45]. These data indicate that in females, but not in males, leptin raises plasma levels of aldosterone, and this latter factor may be causal for vascular inflammation and depression symptoms (see below).

\subsection{Aldosterone as a Risk Factor for Depression}

Data from clinical studies suggest that an elevated level of aldosterone is associated with an increased risk for depression. Male and female depression patients exhibited significantly higher aldosterone levels than matched controls $[46,47]$. Moreover, in patients with premenstrual syndrome, 
increases in plasma aldosterone during the late luteal phase were significantly associated with increases in emotional and physical symptoms $[48,49]$. Spironolactone, a mineralocorticoid-receptor antagonist, relieved the somatic and psychological symptoms of the premenstrual syndrome [48,50]. Together with data from the previous paragraph, it seems that obesity in females increases, through activation of the leptin receptor, the circulating levels of aldosterone. It is presumably aldosterone that ultimately enhances the depression risk. Concerning the mechanism of action, it is known that acute infusion of aldosterone into the human forearm inhibits endothelium-dependent vasorelaxation to acetylcholine [51]. Endothelium-dependent dilatory response to acetylcholine was also impaired in mice with genetic or diet-induced obesity [42,52]. In these latter studies, the vasodilator response was 'rescued' by pretreatment with the mineralocorticoid receptor (MR) antagonist eplerenone, or by endothelium-specific deletion of the MR-gene [52]. In rat cerebral arteries, aldosterone increased superoxide production and raised the transcription of chemokines from endothelial cells [53]. Incubation of endothelial cells from the human umbilical vein with aldosterone increased mRNA and protein levels of the adhesion molecules ICAM1, VCAM1, and selectin-E, but reduced the production of the endothelial vasodilator, nitric oxide [54-57]. These results indicate that aldosterone, via activation of endothelial mineralocorticoid receptors, promotes a proinflammatory state of the endothelium $[43,44,58,59]$. Faulkner et al. [59] have reported that progesterone increases the expression of aldosterone-receptors on endothelial cells. This observation provides a possible explanation of why females are more sensitive to obesity-, leptin- and aldosterone-induced depression than males.

Apart from leptin, there are some additional aldosterone-releasing factors [60]. Typical for West European and North American diets is the consumption of large amounts of the vegetable fatty acid, linoleic acid. This 18-carbon, $\omega-6$ unsaturated fatty acid is oxidized to the compound '12,13-epoxy-9-keto-10(trans)-octadecenoic acid' or 'EKODE' [61]. EKODE (see Figure 1) is a particularly strong activator of aldosterone release from adrenal cells and is detected in substantial amounts in human plasma [60,61]. In blood samples from 24 adults, levels of EKODE correlated with those of aldosterone [61]. In a prospective study in American nurses, a reduction in linoleic acid-intake was associated with a reduction in depression risk $[62,63]$. High EKODE levels are also present in itching psoriatic skin lesions [64]. Consistent with an increase in plasma aldosterone levels [65], psoriasis is associated with ischemic heart disease, cerebrovascular disease, peripheral artery disease [66], hypertension [67], and depression [68]. A link between EKODE and depression has also been provided by a study of Hennebelle et al. [69] in patients with seasonal affective disorder. In this study, EKODE levels were increased during the dysthymic period but were back to normal during the euthymic phase [69]. Whether also the aldosterone levels were elevated during the seasonal affective period was not investigated, unfortunately. 

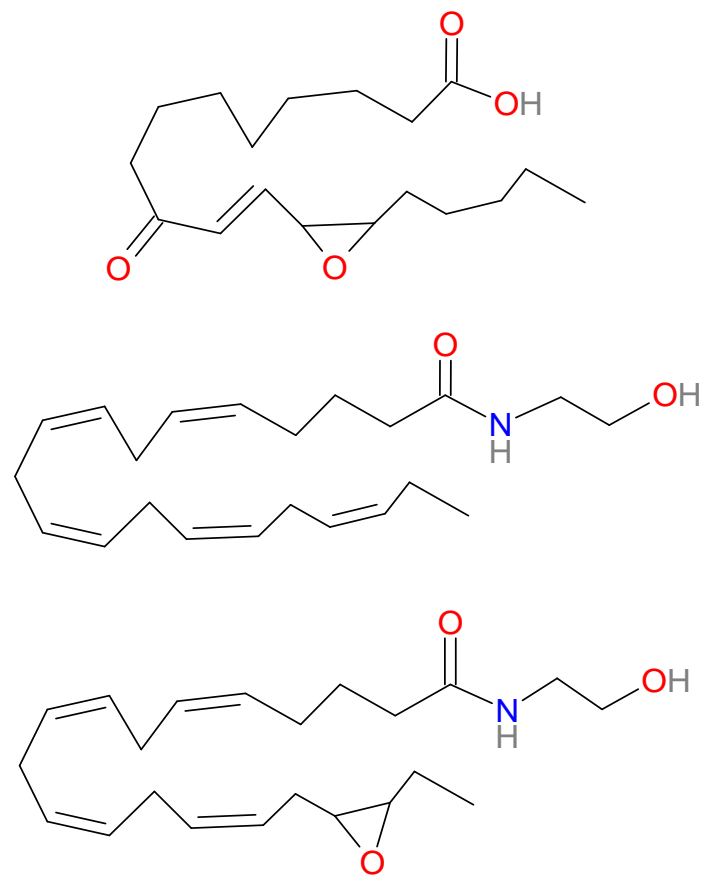

Figure 1. From top to bottom are shown the chemical structures of EKODE, EPEA, and 17,18-EEQ-EA.

\subsection{Old Age as a Risk Factor for Depression}

Comorbidity between cardiovascular disease and depression in the elderly has been recognized for several decades and has led to the formulation of the 'vascular depression' hypothesis [70,71]. This hypothesis proposes that 'cardiovascular disease may predispose, precipitate, or perpetuate some geriatric depressive syndromes' [70]. Geriatric depression is sometimes referred to as late-life depression [27] or as late-onset depression [28], depending on the inclusion/omission of elderly depressed patients who suffered from depression before the age of 40 . In the longitudinal study by Van Agtmaal et al. [27], the presence of white matter hyperintensities and cerebral microinfarctions was associated with depression symptoms in patients older than 40 years of age. This result was corroborated by the meta-analysis by Salo et al. [28], which confirmed that the white matter hyperintensity-burden was particularly pronounced in patients with late-life depression. White matter hyperintensities, seen in magnetic resonance imaging brain scans, are assumed to reflect silent lesions of vascular or ischemic origin in the brain [72]. Such hyperintensities, in principle, can also occur in young patients, for instance, in those at elevated risk for atherosclerotic disease [73,74].

\subsection{Homocysteine and Vascular Inflammation}

High plasma levels of homocysteine are associated with atherosclerosis (for review see [75]) and with male major depressive disorders [26]. The molecular basis for the activity of homocysteine remains undefined, however, several mechanisms that perturb endothelial function have been identified. These include reduced nitric oxide production, enhanced superoxide formation, loss of endothelial glutathione, activation of endothelial NFאB, transcription of MCP1, IL8, ICAM1, and VCAM1, and an increase in pro-thrombotic platelet function [75]. The gender-specific effect of homocysteine levels on depression may be explained by a protective effect of estrogen on endothelial integrity [76].

\subsection{The Endothelium of the Blood-Brain Barrier}

The endothelial layer of cerebral arterioles constitutes one of the physical barriers between the blood circulation, including any circulating proinflammatory cytokines and the brain [77,78]. It is conceivable that endothelial dysfunction, as caused by vascular inflammation, is the underlying factor that explains why depression and cardiovascular disorders co-occur [79-82]. Dysfunction of the 
endothelium is also implicated in disease states like hypercholesterolemia and other dyslipidemias, diabetes, obesity, hypertension, and aging [83]. Endothelial cell dysfunction, including that of the blood-brain barrier, is associated with an increased adherence of leukocytes, platelet activation, stimulation of the coagulation cascade, induction of an inflammatory environment, and formation of atherosclerotic plaques $[57,84]$. It is conceivable that such processes lead to an altered function of the underlying brain tissue, although a detailed understanding of the pathological intricacies is lacking.

\section{Biomarkers for Vascular Inflammation}

\subsection{Flow-Mediated Dilation}

Endothelial dysfunction can be estimated non-invasively by a technique referred to as 'flow-mediated dilation' (FMD) $[85,86]$. Deficits in FMD in peripheral blood vessels are associated with depression symptoms [27,87]. In fact, blunted FMD responses correlate both with the presence and the severity of depression symptoms [79,88-90]. These results make FMD a useful biomarker for depression that is secondary to a vascular inflammatory disorder.

\subsection{Circulating Biomarkers}

Endothelial inflammation involves activation of the nuclear factor- $\mathrm{B}(\mathrm{NF} \kappa \mathrm{B})$ pathway, which in turn, is triggered by multiple factors including C-reactive protein (CRP), cytokines like tumor necrosis factor- $\alpha(\mathrm{TNF} \alpha)$ and interleukin-6 (IL6), RAGE-agonists and molecules derived from pathogenic microorganisms. The $\mathrm{NF} \kappa \mathrm{B}$ pathway promotes transcription of molecules that increase leukocyte-adhesion, such as ICAM1 and VCAM1 [29,91-94]. Circulating levels of CRP, TNF $\alpha$, and IL6 are increased both in patients with atherosclerosis and in patients with depression (see Table 1). Proteolytic cleavage of membrane-bound ICAM1 and VCAM1 results in soluble forms (sICAM1 and sVCAM1, respectively). In soluble form, these products continue to act as proinflammatory agents $[95,96]$, and their increased levels are predictive for the later atherosclerotic disease [96-99]. Therefore, plasma levels of sICAM1 and sVCAM1 might be useful biomarkers for depression associated with vascular inflammation (see $[100,101])$. The von Willebrand factor (vWF) is a further factor that is implicated in the pathogenesis of atherosclerosis. The vWF is involved in macrophage and leukocyte recruitment to inflamed blood vessels [102], in platelet adhesion in stenotic arteries [103], and importantly, is linked to stroke and impairment of the blood-brain barrier function [104-106]. High circulating levels of vWF are seen in myocardial infarction [107], acute coronary artery disease [108], and carotid stenosis [103]. Consistent with the hypothesis that depression can be secondary to vascular inflammation, plasma vWF levels of patients with major depression, independent on their antidepressant treatment, were significantly higher than those of healthy control subjects [82,109-111].

Table 1. Potential Biomarkers for Depression Caused by Vascular Inflammation.

\begin{tabular}{ccc}
\hline Factor & Vascular Inflammation & Major Depressive Disorder \\
\hline CRP & {$[112-115]$} & {$[116-120]$} \\
IL6 & {$[115,121,122]$} & {$[123,124]$} \\
TNF $\alpha$ & {$[125]$} & {$[126,127]$} \\
sICAM1 & {$[96,99]$} & {$[82,100,101,128-130]$} \\
sVCAM1 & {$[97,98]$} & {$[82,100,101,129,130]$} \\
vWF & {$[103-106]$} & {$[82,109-111]$} \\
Aldosterone & {$[43,58,59,131]$} & {$[46,47,49]$} \\
Homocysteine & {$[75]$} & {$[26]$} \\
\hline
\end{tabular}

\section{Treatments}

Data reviewed above indicates that vascular inflammation deteriorates endothelial function, including the blood-brain barrier, and this, presumably, leads to depression. Consequently, treatments 
that prevent or improve endothelial dysfunction could result in antidepressant effects in patients with this particular cause of depression.

\subsection{The Fish-Oil Component Eicosapentaenoic Acid (EPA)}

Zehr and Walker [132] reviewed 22 clinical trials, in which the effect of fish-oil supplementation on endothelium-dependent vasodilation was investigated. In 18 out of these 22 studies, an improved vasodilator effect was found. This included studies in hyperlipidemic individuals, in young cigarette smokers, in patients with type-2 diabetes, and individuals with a high body mass index [132]. The two major constituents of fish-oil are the 20-carbon $\omega 3$-fatty acid eicosapentaenoic acid (EPA) and the 22 -carbon $\omega-3$ fatty acid docosahexaenoic acid (DHA) (for review see $[133,134])$. Supplementation of the diet with fish-oil rapidly increases free circulating levels of EPA and DHA, as well as their levels in membranes of erythrocytes, platelets, and monocytes $[133,135]$. But, whereas DHA is particularly abundant in human retina and brain [135-137], the concentration of EPA in these CNS-tissues is some 250-times lower than that of DHA, despite the fact that EPA and DHA enter the brain at similar rates $[137,138]$. DHA is rapidly incorporated into brain phospholipids to maintain high levels [136], whereas EPA is slowly incorporated and extensively metabolized [138]. These data suggest that DHA is important for brain function, while EPA most likely will have its main function outside the CNS.

Apart from fish-oil, impaired endothelium-dependent blood vessel relaxation was also improved by supplementation with pure EPA [132]. In a prospective cohort study in adults with congestive heart failure, EPA-concentrations, but not DHA-concentrations, were inversely associated with incident coronary heart failure [139]. In a multi-ethnic sample of nearly 3000 adults with atherosclerosis, high EPA plasma levels (or combined DHA and EPA levels) were associated with lower sICAM1 levels [140]. Moreover, EPA supplementation, either as fish-oil or as pure product, has been reported to decrease circulating levels of the adhesion molecules sICAM1 and sVCAM1 [62,141,142]. This effect was noted in both subjects with dyslipidemia and in healthy controls [141]. In contrast, pure DHA failed to affect sICAM1 levels [142]. Large meta-analyses consistently report that the antidepressant activity of EPA is superior to that of DHA [143-146], whereas pure DHA failed to reduce depression [147]. Yang et al. [148] reported a head-to-head comparison of the antidepressant activity of pure EPA and DHA. In this 12-week double-blind, randomized controlled trial, participants with major depressive disorder were randomly assigned to receive EPA, DHA, or a combination of EPA and DHA. The cumulative rates of clinical remission were significantly higher in the EPA and the EPA + DHA group than in the DHA group. Clinical remission correlated with the plasma levels of the EPA-derived endocannabinoid metabolite EPEA (eicosapentaenoyl ethanol-amide; see Figure 1), but not with those of any other endocannabinoid [148]. This observation indicates that the antidepressant effect of EPA might be due to a transformation of EPA to an endogenous cannabinoid metabolite.

\section{2. $C B_{2}$-Receptor Agonists}

Endocannabinoids are an important class of biologically active fatty acid-derivatives [136,149]. They play a role in the cardiovascular system [150], including blood vessels of the blood-brain barrier [151,152], in immune function [137,153,154], and in depression [10,155]. Perhaps the best-studied endocannabinoid is anandamide (arachidonyl ethanolamide, or AEA), an amide formed from ethanolamine and arachidonic acid. Similar to arachidonic acid, cells such as adipocytes are able to convert DHA to DHEA (docosahexaenoyl ethanolamide) and EPA to EPEA [156]. These compounds activate the classical endocannabinoid CB1 and CB2 receptors, and several orphan receptors, including GPR18 [156,157]. Since phytocannabinoids strongly affect mental function, it is conceivable that a receptor-subtype selective compound might display a beneficial effect in major depression. However, no such compound has been introduced to the market.

Similar to free polyunsaturated fatty acids, cyclooxygenase (COX), lipoxygenase (LOX), and cytochrome P450 (CYP) enzymes also oxidize endocannabinoids [137,158-160]. CYP $\omega-3$ epoxidases oxidize EPEA and DHEA to EEQ-EA (Figure 1) and EDP-EA, respectively [160]. 
These anti-inflammatory products were observed in significant amounts in the brain and peripheral tissues of the rat [160]. Moreover, EEQ-EA and EDP-EA exert vasodilator activity in bovine coronary arteries and inhibit platelet aggregation [160,161]. Epoxidation of AEA and EPEA greatly altered the CB1/CB2 profile by causing a profound shift towards higher CB2 affinity [160]. In contrast, the affinity of DHEA and its $\omega-3$ epoxidation product EDP-EA for CB1 and CB2 receptors was 100 to 1000-fold less than that of the arachidonic acid and EPA derivatives [160]. Thus, the DHA-derived oxidized endocannabinoid EDP-EA failed to bind to CB2-receptors, whereas the equivalent EPA-derived mediator (EEQ-EA) was highly potent and selective for CB2-receptors. This represents a major difference between the EPA- and DHA-derived mediators and potentially could explain the difference in antidepressant activity since there is ample evidence that stimulation of endothelial CB2 receptors counteracts increases in ICAM1 and VCAM1 [162-164]. The beneficial role of CB2-receptor agonists in endothelial dysfunction [165] could result in antidepressant activity in depression caused by vascular inflammation.

\subsection{Vagus Nerve Stimulation}

Stimulation of the left cervical Vagus nerve is an approved therapy for 'treatment-resistant' depression [166-168]. The cholinergic anti-inflammatory pathway [169] is part of a neural reflex circuit that detects peripheral inflammation and provides regulatory feedback to suppress an excessive activation of the innate immune system [170,171]. The efferent limb of the Vagus nerve provides parasympathetic innervation to multiple organ systems, including the vascular endothelium [172,173]. An important cholinergic receptor-subtype that is activated by Vagus nerve- stimulation is the nicotinic receptor $\alpha 7$ ( $\alpha 7 \mathrm{nAChR})$ [174]. In endothelial cells from human umbilical vein, stimulation of $\alpha 7 \mathrm{nACh}$-receptors by nicotine or acetylcholine inhibited the activation of the NFkB pathway and transcription of proinflammatory cytokines and chemokines [172]. Moreover, stimulation of endothelial $\alpha 7 \mathrm{nACh}$-receptors reduced inflammation-induced expression of VCAM1, ICAM1 and E-selectin, and the subsequent trans-endothelial migration of leukocytes [172]. In rodent models, activation of $\alpha 7 \mathrm{nACh}$-receptors improved atherosclerosis [175], triglyceride levels, weight gain, metabolic syndrome [176,177], and heart rate variability [178]. Collectively, these data indicate that Vagus nerve-stimulation and $\alpha 7 \mathrm{nACh}$-selective agonists could be useful in the treatment of depression that is secondary to vascular inflammation.

\subsection{Histone Deacetylase inhibition}

The clearance of apoptotic neutrophils by monocytes/macrophages is a crucial aspect of atherosclerosis since its failure hampers the resolution of vascular inflammation [179]. Whereas inflammatory molecules like LPS (lipo-polysaccharide) or TNF $\alpha$ delay the apoptosis of aged neutrophils [180], histone deacetylase inhibitors (e.g., short-chain fatty acids like propionate, butyrate, or valproate) increase the apoptosis of neutrophils [180]. Valproate and butyrate increased the clearance of apoptotic neutrophils by macrophages and reduced zymosan-induced peritonitis in mice [181]. These histone deacetylase (HDAC) inhibitors were found to suppress the LPS-induced release of IL6 and TNF $\alpha$ [181]. Interestingly, propionate and butyrate are generated through microbial fermentation of otherwise indigestible carbohydrate fibers [12], providing an explanation for the notion that fiber-rich food is good for health [182]. Valproate significantly reduced atherosclerosis in laboratory animals $[183,184]$, whereas valproate and butyrate displayed anti-inflammatory and neuroprotective effects in an animal model of stroke [185]. In addition, genetic disruption of the HDAC3 gene in endothelial cells from human umbilical vein, inhibited NFKB-signaling, reduced the expression of VCAM1 and suppressed monocyte adhesion [186]. Consistent with the preclinical data, in epidemiological studies, valproate seems to be effective for primary and secondary prevention of stroke [187,188] and for myocardial infarction [189]. Although not thoroughly investigated, available data indicate that valproate possesses antidepressant activity too [190-192]. Based on this information, HDAC inhibition could represent a specific treatment for vascular inflammation-induced depression. 


\section{Discussion}

Although many depressed patients display elevated levels of proinflammatory cytokines, this is not the case in every patient $[116,193,194]$. If we assume that all forms of depression are due to inflammation, then in some patients, the inflammation is not traceable in the blood. The alternative is that there are forms of depression that are unrelated to inflammatory events (but in that case, there is currently no clue about the cause of this form of depression). The present review has focused on depression associated with elevated levels of proinflammatory cytokines in the circulation, a form of depression that has been described as 'inflammatory cytokine associated depression (ICAD)' [4]. In this subgroup of depression patients, the peripheral inflammation took place before the onset of depression symptoms $[5,8,116]$. The focus on this subtype is considered justifiable, since high levels of IL6, soluble IL-6 receptor (sIL6R), or TNF $\alpha$ generally indicate a poor response to conventional antidepressants $[8,117,195-197]$. Notably, a poor response to antidepressant treatment occurs in $30-50 \%$ of patients with major depressive disorder [198]. In the case of chronic non-resolving disorders like autoimmune diseases, but also for lifestyle and diet-related disorders like obesity, type-2 diabetes, or smoking-induced atherosclerosis, it is likely that the poor response to classical antidepressants is due to the persistence of the inflammatory process. Lotrich [4] suggested that depression secondary to vascular inflammation might be more responsive to other medications than to classical antidepressants. As the mechanism of action of the treatments proposed in the present review is complementary to the central effects by traditional antidepressants, it is expected that they will augment the clinical response to current treatment (see Figure 2).

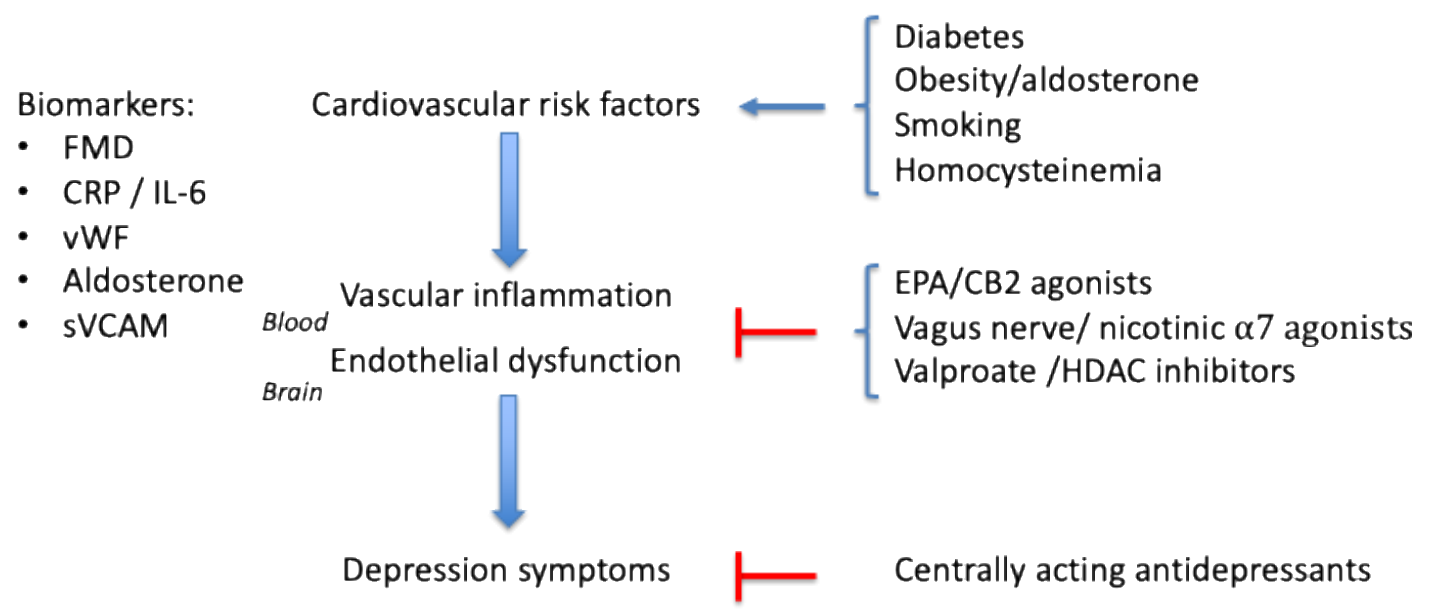

Figure 2. Diabetes and other risk factors for atherosclerosis promote vascular inflammation and endothelial dysfunction. Biomarkers for this process are FMD (flow-mediated dilation), CRP (C-reactive protein), proinflammatory cytokines like interleukin-6, von Willebrand factor (vWF), aldosterone, or soluble vascular cell adhesion molecule (sVCAM). Putative treatments specific for depression secondary to vascular inflammation are eicosapentaenoic acid (EPA), cannabis CB2 receptor agonists, Vagus nerve stimulation, agonists for the nicotinic $\alpha 7$ receptors, and HDAC (histone deacetylase) inhibitors, like valproate.

Presently, terms like 'ICAD' or 'vascular depression' are not generally accepted and are not entities acknowledged in disease classification systems such as DSM or ICD. Similarly, the therapeutic use of valproate, EPA, Vagus nerve-stimulation in depression is currently not firmly established. It is the author's opinion that progress in the treatment of major depression is achievable if we would recognize that depressive symptoms occur as a consequence of vascular inflammation. For this purpose, the current review has proposed a number of biomarkers. These biomarkers would enable stratification of depressed patients into those with and those without vascular inflammation. Rapaport et al. [199] have published a motivating example of this approach. They tested pure EPA and pure DHA and 
obtained evidence for a therapeutic effect of EPA in depressed patients with high levels of peripheral inflammation markers, while without patient stratification, the effect of EPA would have been missed.

Funding: This research received no external funding.

Acknowledgments: The author would like to thank M. Hersberger (Division of Clinical Chemistry and Biochemistry, University Children's Hospital Zurich, CH-8032 Zurich, Switzerland) and G. Berger (Child and Adolescent Psychiatry Research Centre, Department of Child and Adolescent Psychiatry and Psychotherapy, University of Zurich, $\mathrm{CH}-8032$ Zurich, Switzerland) for their numerous stimulating discussions. I would also like to thank S. Walitza (Psychiatric University Hospital, University of Zurich) for granting access to the library services of the University, and J. Nozulak (retired chemist) for the preparation of Figure 1.

Conflicts of Interest: The author declares no conflict of interest.

\section{List of Abbreviations}

CRP (C-reactive protein), DHA (docosahexaenoic acid), EPA (eicosapentaenoic acid), FMD (flow-mediated dilation), HDAC (histone deacetylase), ICAD (inflammatory cytokine associated depression), ICAM (intercellular cell adhesion molecule), IL (interleukin), LPS (lipopolysaccharide), MCP1 (monocyte chemotactic protein-1), MR (mineralocorticoid receptor), NFKB (nuclear factor- $\mathrm{KB}$ ), TLR4 (Toll-like receptor-4), TNF $\alpha$ (tumor necrosis factor- $\alpha$ ), VCAM (vascular cell adhesion molecule), VLDL (very-low-density lipoprotein) and vWF (von Willebrand factor).

\section{References}

1. Littrell, J.L. Taking the perspective that a depressive state reflects inflammation: Implications for the use of antidepressants. Front. Psychol. 2012, 3, 297. [CrossRef]

2. Benros, M.E.; Waltoft, B.L.; Nordentoft, M.; Ostergaard, S.D.; Eaton, W.W.; Krogh, J.; Mortensen, P.B. Autoimmune diseases and severe infections as risk factors for mood disorders: A nationwide study. JAMA Psychiatry 2013, 70, 812-820. [CrossRef] [PubMed]

3. Berk, M.; Williams, L.J.; Jacka, F.N.; O’Neil, A.; Pasco, J.A.; Moylan, S.; Allen, N.B.; Stuart, A.L.; Hayley, A.C.; Byrne, M.L.; et al. So depression is an inflammatory disease, but where does the inflammation come from? BMC Med. 2013, 11, 200. [CrossRef] [PubMed]

4. Lotrich, F.E. Inflammatory cytokine-associated depression. Brain. Res. 2015, 1617, 113-125. [CrossRef] [PubMed]

5. Zalli, A.; Jovanova, O.; Hoogendijk, W.J.; Tiemeier, H.; Carvalho, L.A. Low-grade inflammation predicts persistence of depressive symptoms. Psychopharmacology (Berl.) 2016, 233, 1669-1678. [CrossRef]

6. Vogelzangs, N.; De Jonge, P.; Smit, J.H.; Bahn, S.; Penninx, B.W. Cytokine production capacity in depression and anxiety. Transl. Psychiatry 2016, 6, e825. [CrossRef]

7. Young, J.J.; Bruno, D.; Pomara, N. A review of the relationship between proinflammatory cytokines and major depressive disorder. J. Affect. Disord. 2014, 169, 15-20. [CrossRef]

8. Hodes, G.E.; Menard, C.; Russo, S.J. Integrating interleukin-6 into depression diagnosis and treatment. Neurobiol. Stress 2016, 4, 15-22. [CrossRef]

9. Kohler, C.A.; Freitas, T.H.; Stubbs, B.; Maes, M.; Solmi, M.; Veronese, N.; De Andrade, N.Q.; Morris, G.; Fernandes, B.S.; Brunoni, A.R.; et al. Peripheral alterations in cytokine and chemokine levels after antidepressant drug treatment for major depressive disorder: Systematic review and meta-analysis. Mol. Neurobiol. 2018, 55, 4195-4206. [CrossRef]

10. Boorman, E.; Zajkowska, Z.; Ahmed, R.; Pariante, C.M.; Zunszain, P.A. Crosstalk between endocannabinoid and immune systems: A potential dysregulation in depression? Psychopharmacology (Berl.) 2016, 233, 1591-1604. [CrossRef]

11. Khandaker, G.M.; Dantzer, R.; Jones, P.B. Immunopsychiatry: Important facts. Psychol. Med. 2017, 47, 2229-2237. [CrossRef]

12. Holzer, P.; Farzi, A.; Hassan, A.M.; Zenz, G.; Jacan, A.; Reichmann, F. Visceral inflammation and immune activation stress the brain. Front. Immunol. 2017, 8, 1613. [CrossRef] [PubMed]

13. Baruah, J.; Vasudevan, A. The vessels shaping mental health or illness. Open Neurol. J. 2019, 13, 1-9. [CrossRef] [PubMed]

14. Tiemeier, H.; Van Dijck, W.; Hofman, A.; Witteman, J.C.; Stijnen, T.; Breteler, M.M. Relationship between atherosclerosis and late-life depression: The rotterdam study. Arch. Gen. Psychiatry 2004, 61, 369-376. [CrossRef] [PubMed] 
15. Chen, S.; Zhang, Q.; Dai, G.; Hu, J.; Zhu, C.; Su, L.; Wu, X. Association of depression with pre-diabetes, undiagnosed diabetes, and previously diagnosed diabetes: A meta-analysis. Endocrine 2016, 53, 35-46. [CrossRef]

16. Chireh, B.; Li, M.; D'Arcy, C. Diabetes increases the risk of depression: A systematic review, meta-analysis and estimates of population attributable fractions based on prospective studies. Prev. Med. Rep. 2019, 14, 100822. [CrossRef]

17. Gan, Y.; Gong, Y.; Tong, X.; Sun, H.; Cong, Y.; Dong, X.; Wang, Y.; Xu, X.; Yin, X.; Deng, J.; et al. Depression and the risk of coronary heart disease: A meta-analysis of prospective cohort studies. BMC Psychiatry 2014, 14, 371. [CrossRef]

18. Carney, R.M.; Freedland, K.E. Depression and coronary heart disease. Nat. Rev. Cardiol. 2017, 14, $145-155$. [CrossRef]

19. Lauzon, C.; Beck, C.A.; Huynh, T.; Dion, D.; Racine, N.; Carignan, S.; Diodati, J.G.; Charbonneau, F.; Dupuis, R.; Pilote, L. Depression and prognosis following hospital admission because of acute myocardial infarction. CMAJ 2003, 168, 547-552.

20. Gottlieb, S.S.; Khatta, M.; Friedmann, E.; Einbinder, L.; Katzen, S.; Baker, B.; Marshall, J.; Minshall, S.; Robinson, S.; Fisher, M.L.; et al. The influence of age, gender, and race on the prevalence of depression in heart failure patients. J. Am. Coll. Cardiol. 2004, 43, 1542-1549. [CrossRef]

21. Rutledge, T.; Reis, V.A.; Linke, S.E.; Greenberg, B.H.; Mills, P.J. Depression in heart failure a meta-analytic review of prevalence, intervention effects, and associations with clinical outcomes. J. Am. Coll. Cardiol. 2006, 48, 1527-1537. [CrossRef] [PubMed]

22. Pasco, J.A.; Williams, L.J.; Jacka, F.N.; Ng, F.; Henry, M.J.; Nicholson, G.C.; Kotowicz, M.A.; Berk, M. Tobacco smoking as a risk factor for major depressive disorder: Population-based study. Br. J. Psychiatry 2008, 193, 322-326. [CrossRef] [PubMed]

23. Capuron, L.; Lasselin, J.; Castanon, N. Role of adiposity-driven inflammation in depressive morbidity. Neuropsychopharmacology 2017, 42, 115-128. [CrossRef] [PubMed]

24. Pan, A.; Keum, N.; Okereke, O.I.; Sun, Q.; Kivimaki, M.; Rubin, R.R.; Hu, F.B. Bidirectional association between depression and metabolic syndrome: A systematic review and meta-analysis of epidemiological studies. Diabetes Care 2012, 35, 1171-1180. [CrossRef] [PubMed]

25. Rajan, T.M.; Menon, V. Psychiatric disorders and obesity: A review of association studies. J. Postgrad. Med. 2017, 63, 182-190. [PubMed]

26. Nabi, H.; Bochud, M.; Glaus, J.; Lasserre, A.M.; Waeber, G.; Vollenweider, P.; Preisig, M. Association of serum homocysteine with major depressive disorder: Results from a large population-based study. Psychoneuroendocrinology 2013, 38, 2309-2318. [CrossRef]

27. Van Agtmaal, M.J.M.; Houben, A.; Pouwer, F.; Stehouwer, C.D.A.; Schram, M.T. Association of microvascular dysfunction with late-life depression: A systematic review and meta-analysis. JAMA Psychiatry 2017, 74, 729-739. [CrossRef]

28. Salo, K.I.; Scharfen, J.; Wilden, I.D.; Schubotz, R.I.; Holling, H. Confining the concept of vascular depression to late-onset depression: A meta-analysis of mri-defined hyperintensity burden in major depressive disorder and bipolar disorder. Front. Psychol. 2019, 10, 1241. [CrossRef]

29. Paneni, F.; Beckman, J.A.; Creager, M.A.; Cosentino, F. Diabetes and vascular disease: Pathophysiology, clinical consequences, and medical therapy: Part i. Eur. Heart. J. 2013, 34, 2436-2443. [CrossRef]

30. Schmidt, A.M.; Yan, S.D.; Wautier, J.L.; Stern, D. Activation of receptor for advanced glycation end products: A mechanism for chronic vascular dysfunction in diabetic vasculopathy and atherosclerosis. Circ. Res. 1999, 84, 489-497. [CrossRef]

31. Vistoli, G.; De Maddis, D.; Cipak, A.; Zarkovic, N.; Carini, M.; Aldini, G. Advanced glycoxidation and lipoxidation end products (ages and ales): An overview of their mechanisms of formation. Free Radic. Res. 2013, 47 (Suppl. 1), 3-27. [CrossRef] [PubMed]

32. Guo, Z.J.; Niu, H.X.; Hou, F.F.; Zhang, L.; Fu, N.; Nagai, R.; Lu, X.; Chen, B.H.; Shan, Y.X.; Tian, J.W.; et al. Advanced oxidation protein products activate vascular endothelial cells via a rage-mediated signaling pathway. Antioxid. Redox Signal. 2008, 10, 1699-1712. [CrossRef] [PubMed]

33. Lee, J.Y.; Sohn, K.H.; Rhee, S.H.; Hwang, D. Saturated fatty acids, but not unsaturated fatty acids, induce the expression of cyclooxygenase-2 mediated through toll-like receptor 4. J. Biol. Chem. 2001, 276, 16683-16689. [CrossRef] [PubMed] 
34. Dhananjayan, R.; Koundinya, K.S.; Malati, T.; Kutala, V.K. Endothelial dysfunction in type 2 diabetes mellitus. Indian J. Clin. Biochem. 2016, 31, 372-379. [CrossRef] [PubMed]

35. Van Harten, B.; De Leeuw, F.E.; Weinstein, H.C.; Scheltens, P.; Biessels, G.J. Brain imaging in patients with diabetes: A systematic review. Diabetes Care 2006, 29, 2539-2548. [CrossRef]

36. Williams, K.J.; Wu, X. Imbalanced insulin action in chronic over nutrition: Clinical harm, molecular mechanisms, and a way forward. Atherosclerosis 2016, 247, 225-282. [CrossRef] [PubMed]

37. Onyike, C.U.; Crum, R.M.; Lee, H.B.; Lyketsos, C.G.; Eaton, W.W. Is obesity associated with major depression? Results from the third national health and nutrition examination survey. Am. J. Epidemiol. 2003, 158, 1139-1147. [CrossRef]

38. De Wit, L.; Luppino, F.; Van Straten, A.; Penninx, B.; Zitman, F.; Cuijpers, P. Depression and obesity: A meta-analysis of community-based studies. Psychiatry Res. 2010, 178, 230-235. [CrossRef]

39. Li, L.; Gower, B.A.; Shelton, R.C.; Wu, X. Gender-specific relationship between obesity and major depression. Front. Endocrinol. (Lausanne) 2017, 8, 292. [CrossRef]

40. Xue, B.; Yu, Y.; Zhang, Z.; Guo, F.; Beltz, T.G.; Thunhorst, R.L.; Felder, R.B.; Johnson, A.K. Leptin mediates high-fat diet sensitization of angiotensin ii-elicited hypertension by upregulating the brain renin-angiotensin system and inflammation. Hypertension 2016, 67, 970-976. [CrossRef]

41. Perez-Cornago, A.; De la Iglesia, R.; Lopez-Legarrea, P.; Abete, I.; Navas-Carretero, S.; Lacunza, C.I.; Lahortiga, F.; Martinez-Gonzalez, M.A.; Martinez, J.A.; Zulet, M.A. A decline in inflammation is associated with less depressive symptoms after a dietary intervention in metabolic syndrome patients: A longitudinal study. Nutr. J. 2014, 13, 36. [CrossRef] [PubMed]

42. Briones, A.M.; Nguyen Dinh Cat, A.; Callera, G.E.; Yogi, A.; Burger, D.; He, Y.; Correa, J.W.; Gagnon, A.M.; Gomez-Sanchez, C.E.; Gomez-Sanchez, E.P.; et al. Adipocytes produce aldosterone through calcineurin-dependent signaling pathways: Implications in diabetes mellitus-associated obesity and vascular dysfunction. Hypertension 2012, 59, 1069-1078. [CrossRef] [PubMed]

43. Huby, A.C.; Otvos, L., Jr.; Belin de Chantemele, E.J. Leptin induces hypertension and endothelial dysfunction via aldosterone-dependent mechanisms in obese female mice. Hypertension 2016, 67, 1020-1028. [CrossRef] [PubMed]

44. Faulkner, J.L.; Belin de Chantemele, E.J. Sex differences in mechanisms of hypertension associated with obesity. Hypertension 2018, 71, 15-21. [CrossRef]

45. Goodfriend, T.L.; Kelley, D.E.; Goodpaster, B.H.; Winters, S.J. Visceral obesity and insulin resistance are associated with plasma aldosterone levels in women. Obes. Res. 1999, 7, 355-362. [CrossRef]

46. Murck, H.; Held, K.; Ziegenbein, M.; Kunzel, H.; Koch, K.; Steiger, A. The renin-angiotensin-aldosterone system in patients with depression compared to controls-A sleep endocrine study. BMC Psychiatry 2003, 3, 15. [CrossRef]

47. Emanuele, E.; Geroldi, D.; Minoretti, P.; Coen, E.; Politi, P. Increased plasma aldosterone in patients with clinical depression. Arch. Med. Res. 2005, 36, 544-548. [CrossRef]

48. O'Brien, P.M.; Craven, D.; Selby, C.; Symonds, E.M. Treatment of premenstrual syndrome by spironolactone. Br. J. Obstet. Gynaecol. 1979, 86, 142-147. [CrossRef]

49. Rosenfeld, R.; Livne, D.; Nevo, O.; Dayan, L.; Milloul, V.; Lavi, S.; Jacob, G. Hormonal and volume dysregulation in women with premenstrual syndrome. Hypertension 2008, 51, 1225-1230. [CrossRef]

50. Wang, M.; Hammarback, S.; Lindhe, B.A.; Backstrom, T. Treatment of premenstrual syndrome by spironolactone: A double-blind, placebo-controlled study. Acta Obstet. Gynecol. Scand. 1995, 74, 803-808. [CrossRef]

51. Farquharson, C.A.; Struthers, A.D. Aldosterone induces acute endothelial dysfunction in vivo in humans: Evidence for an aldosterone-induced vasculopathy. Clin. Sci. (Lond.) 2002, 103, 425-431. [CrossRef] [PubMed]

52. Schafer, N.; Lohmann, C.; Winnik, S.; Van Tits, L.J.; Miranda, M.X.; Vergopoulos, A.; Ruschitzka, F.; Nussberger, J.; Berger, S.; Luscher, T.F.; et al. Endothelial mineralocorticoid receptor activation mediates endothelial dysfunction in diet-induced obesity. Eur. Heart J. 2013, 34, 3515-3524. [CrossRef] [PubMed]

53. Dinh, Q.N.; Young, M.J.; Evans, M.A.; Drummond, G.R.; Sobey, C.G.; Chrissobolis, S. Aldosterone-induced oxidative stress and inflammation in the brain are mediated by the endothelial cell mineralocorticoid receptor. Brain. Res. 2016, 1637, 146-153. [CrossRef] [PubMed] 
54. Hashikabe, Y.; Suzuki, K.; Jojima, T.; Uchida, K.; Hattori, Y. Aldosterone impairs vascular endothelial cell function. J. Cardiovasc. Pharmacol. 2006, 47, 609-613. [CrossRef] [PubMed]

55. Krug, A.W.; Kopprasch, S.; Ziegler, C.G.; Dippong, S.; Catar, R.A.; Bornstein, S.R.; Morawietz, H.; Gekle, M. Aldosterone rapidly induces leukocyte adhesion to endothelial cells: A new link between aldosterone and arteriosclerosis? Hypertension 2007, 50, e156-e157. [CrossRef] [PubMed]

56. Caprio, M.; Newfell, B.G.; La Sala, A.; Baur, W.; Fabbri, A.; Rosano, G.; Mendelsohn, M.E.; Jaffe, I.Z. Functional mineralocorticoid receptors in human vascular endothelial cells regulate intercellular adhesion molecule-1 expression and promote leukocyte adhesion. Circ. Res. 2008, 102, 1359-1367. [CrossRef] [PubMed]

57. Marzolla, V.; Armani, A.; Mammi, C.; Moss, M.E.; Pagliarini, V.; Pontecorvo, L.; Antelmi, A.; Fabbri, A.; Rosano, G.; Jaffe, I.Z.; et al. Essential role of icam-1 in aldosterone-induced atherosclerosis. Int. J. Cardiol. 2017, 232, 233-242. [CrossRef]

58. Liu, G.; Yin, G.S.; Tang, J.Y.; Ma, D.J.; Ru, J.; Huang, X.H. Endothelial dysfunction in patients with primary aldosteronism: A biomarker of target organ damage. J. Hum. Hypertens 2014, 28, 711-715. [CrossRef]

59. Faulkner, J.L.; Kennard, S.; Huby, A.C.; Antonova, G.; Lu, Q.; Jaffe, I.Z.; Patel, V.S.; Fulton, D.J.R.; Belin de Chantemele, E.J. Progesterone predisposes females to obesity-associated leptin-mediated endothelial dysfunction via upregulating endothelial $\mathrm{mr}$ (mineralocorticoid receptor) expression. Hypertension 2019, 74, 678-686. [CrossRef]

60. Kawarazaki, W.; Fujita, T. The role of aldosterone in obesity-related hypertension. Am. J. Hypertens 2016, 29, 415-423. [CrossRef]

61. Goodfriend, T.L.; Ball, D.L.; Egan, B.M.; Campbell, W.B.; Nithipatikom, K. Epoxy-keto derivative of linoleic acid stimulates aldosterone secretion. Hypertension 2004, 43, 358-363. [CrossRef] [PubMed]

62. Lopez-Garcia, E.; Schulze, M.B.; Manson, J.E.; Meigs, J.B.; Albert, C.M.; Rifai, N.; Willett, W.C.; Hu, F.B. Consumption of (n-3) fatty acids is related to plasma biomarkers of inflammation and endothelial activation in women. J. Nutr. 2004, 134, 1806-1811. [CrossRef] [PubMed]

63. Lucas, M.; Mirzaei, F.; O’Reilly, E.J.; Pan, A.; Willett, W.C.; Kawachi, I.; Koenen, K.; Ascherio, A. Dietary intake of n-3 and n-6 fatty acids and the risk of clinical depression in women: A 10-y prospective follow-up study. Am. J. Clin. Nutr. 2011, 93, 1337-1343. [CrossRef] [PubMed]

64. Ramsden, C.E.; Domenichiello, A.F.; Yuan, Z.X.; Sapio, M.R.; Keyes, G.S.; Mishra, S.K.; Gross, J.R.; Majchrzak-Hong, S.; Zamora, D.; Horowitz, M.S.; et al. A systems approach for discovering linoleic acid derivatives that potentially mediate pain and itch. Sci. Signal 2017, 10, eaal5241. [CrossRef]

65. Van de Kerkhof, P.C. Plasma aldosterone and cortisol levels in psoriasis and atopic dermatitis. Br. J. Dermatol. 1982, 106, 423-427. [CrossRef]

66. Patel, R.V.; Shelling, M.L.; Prodanovich, S.; Federman, D.G.; Kirsner, R.S. Psoriasis and vascular disease-risk factors and outcomes: A systematic review of the literature. J. Gen. Intern. Med. 2011, 26, 1036-1049. [CrossRef]

67. Takeshita, J.; Wang, S.; Shin, D.B.; Mehta, N.N.; Kimmel, S.E.; Margolis, D.J.; Troxel, A.B.; Gelfand, J.M. Effect of psoriasis severity on hypertension control: A population-based study in the united kingdom. JAMA Dermatol. 2015, 151, 161-169. [CrossRef]

68. Esposito, M.; Saraceno, R.; Giunta, A.; Maccarone, M.; Chimenti, S. An italian study on psoriasis and depression. Dermatology 2006, 212, 123-127. [CrossRef]

69. Hennebelle, M.; Otoki, Y.; Yang, J.; Hammock, B.D.; Levitt, A.J.; Taha, A.Y.; Swardfager, W. Altered soluble epoxide hydrolase-derived oxylipins in patients with seasonal major depression: An exploratory study. Psychiatry Res. 2017, 252, 94-101. [CrossRef]

70. Alexopoulos, G.S.; Meyers, B.S.; Young, R.C.; Campbell, S.; Silbersweig, D.; Charlson, M. 'Vascular depression' hypothesis. Arch. Gen. Psychiatry 1997, 54, 915-922. [CrossRef]

71. Musselman, D.L.; Evans, D.L.; Nemeroff, C.B. The relationship of depression to cardiovascular disease: Epidemiology, biology, and treatment. Arch. Gen. Psychiatry 1998, 55, 580-592. [CrossRef] [PubMed]

72. Lavretsky, H.; Zheng, L.; Weiner, M.W.; Mungas, D.; Reed, B.; Kramer, J.H.; Jagust, W.; Chui, H.; Mack, W.J. The mri brain correlates of depressed mood, anhedonia, apathy, and anergia in older adults with and without cognitive impairment or dementia. Int. J. Geriatr. Psychiatry 2008, 23, 1040-1050. [CrossRef] [PubMed]

73. Baldwin, R.C.; O’Brien, J. Vascular basis of late-onset depressive disorder. Br. J. Psychiatry 2002, 180, 157-160. [CrossRef] 
74. Messner, B.; Bernhard, D. Smoking and cardiovascular disease: Mechanisms of endothelial dysfunction and early atherogenesis. Arterioscler. Thromb. Vasc. Biol. 2014, 34, 509-515. [CrossRef] [PubMed]

75. Esse, R.; Barroso, M.; Tavares de Almeida, I.; Castro, R. The contribution of homocysteine metabolism disruption to endothelial dysfunction: State-of-the-art. Int. J. Mol. Sci. 2019, 20, 867. [CrossRef] [PubMed]

76. Dimitrova, K.R.; DeGroot, K.; Myers, A.K.; Kim, Y.D. Estrogen and homocysteine. Cardiovasc. Res. 2002, 53, 577-588. [CrossRef]

77. Erickson, M.A.; Banks, W.A. Neuroimmune axes of the blood-brain barriers and blood-brain interfaces: Bases for physiological regulation, disease states, and pharmacological interventions. Pharmacol. Rev. 2018, 70, 278-314. [CrossRef] [PubMed]

78. Capuron, L.; Miller, A.H. Immune system to brain signaling: Neuropsychopharmacological implications. Pharmacol. Ther. 2011, 130, 226-238. [CrossRef]

79. Rajagopalan, S.; Brook, R.; Rubenfire, M.; Pitt, E.; Young, E.; Pitt, B. Abnormal brachial artery flow-mediated vasodilation in young adults with major depression. Am. J. Cardiol. 2001, 88, 196-198. [CrossRef]

80. Rybakowski, J.K.; Wykretowicz, A.; Heymann-Szlachcinska, A.; Wysocki, H. Impairment of endothelial function in unipolar and bipolar depression. Biol. Psychiatry 2006, 60, 889-891. [CrossRef]

81. Shi, H.; Feng, G.; Wang, Z.; Zhou, C.; Zhong, G.; Hu, Y.; Wang, G. Relationships between depressive symptoms and endothelial function among outpatients of a general hospital in china. Med. Sci. Monit. 2015, 21, 1812-1819. [PubMed]

82. Van Dooren, F.E.; Schram, M.T.; Schalkwijk, C.G.; Stehouwer, C.D.; Henry, R.M.; Dagnelie, P.C.; Schaper, N.C.; Van der Kallen, C.J.; Koster, A.; Sep, S.J.; et al. Associations of low grade inflammation and endothelial dysfunction with depression-The maastricht study. Brain. Behav. Immun. 2016, 56, 390-396. [CrossRef] [PubMed]

83. Gimbrone, M.A., Jr.; Garcia-Cardena, G. Endothelial cell dysfunction and the pathobiology of atherosclerosis. Circ. Res. 2016, 118, 620-636. [CrossRef] [PubMed]

84. Tomaschitz, A.; Pilz, S.; Ritz, E.; Grammer, T.; Amrein, K.; Merger, S.; Meinitzer, A.; Winkelmann, B.R.; Boehm, B.O.; Marz, W. Relationship between plasma aldosterone concentration and soluble cellular adhesion molecules in patients referred to coronary angiography. Exp. Clin. Endocrinol. Diabetes 2011, 119, 649-655. [CrossRef]

85. Al-Qaisi, M.; Kharbanda, R.K.; Mittal, T.K.; Donald, A.E. Measurement of endothelial function and its clinical utility for cardiovascular risk. Vasc. Health Risk Manag. 2008, 4, 647-652. [CrossRef]

86. Onkelinx, S.; Cornelissen, V.; Goetschalckx, K.; Thomaes, T.; Verhamme, P.; Vanhees, L. Reproducibility of different methods to measure the endothelial function. Vasc. Med. 2012, 17, 79-84. [CrossRef]

87. Cooper, D.C.; Tomfohr, L.M.; Milic, M.S.; Natarajan, L.; Bardwell, W.A.; Ziegler, M.G.; Dimsdale, J.E. Depressed mood and flow-mediated dilation: A systematic review and meta-analysis. Psychosom. Med. 2011, 73, 360-369. [CrossRef]

88. Chrapko, W.E.; Jurasz, P.; Radomski, M.W.; Lara, N.; Archer, S.L.; Le Melledo, J.M. Decreased platelet nitric oxide synthase activity and plasma nitric oxide metabolites in major depressive disorder. Biol. Psychiatry 2004, 56, 129-134. [CrossRef]

89. Garcia, R.G.; Zarruk, J.G.; Barrera, C.; Pinzon, A.; Trillos, E.; Arenas, W.D.; Luengas, C.; Tomaz, C.; Lopez-Jaramillo, P. Plasma nitrate levels and flow-mediated vasodilation in untreated major depression. Psychosom. Med. 2011, 73, 344-349. [CrossRef]

90. Greaney, J.L.; Saunders, E.F.H.; Santhanam, L.; Alexander, L.M. Oxidative stress contributes to microvascular endothelial dysfunction in men and women with major depressive disorder. Circ. Res. 2019, 124, 564-574. [CrossRef]

91. Ledebur, H.C.; Parks, T.P. Transcriptional regulation of the intercellular adhesion molecule-1 gene by inflammatory cytokines in human endothelial cells. Essential roles of a variant nf-kappa b site and p65 homodimers. J. Biol. Chem. 1995, 270, 933-943. [CrossRef] [PubMed]

92. Kawanami, D.; Maemura, K.; Takeda, N.; Harada, T.; Nojiri, T.; Saito, T.; Manabe, I.; Imai, Y.; Nagai, R. $\mathrm{C}$-reactive protein induces vcam-1 gene expression through nf-kappab activation in vascular endothelial cells. Atherosclerosis 2006, 185, 39-46. [CrossRef] [PubMed]

93. Zapolska-Downar, D.; Siennicka, A.; Kaczmarczyk, M.; Kolodziej, B.; Naruszewicz, M. Butyrate inhibits cytokine-induced vcam-1 and icam-1 expression in cultured endothelial cells: The role of nf-kappab and pparalpha. J. Nutr. Biochem. 2004, 15, 220-228. [CrossRef] 
94. Milstone, D.S.; Ilyama, M.; Chen, M.; O’Donnell, P.; Davis, V.M.; Plutzky, J.; Brown, J.D.; Haldar, S.M.; Siu, A.; Lau, A.C.; et al. Differential role of an nf-kappab transcriptional response element in endothelial versus intimal cell vcam-1 expression. Circ. Res. 2015, 117, 166-177. [CrossRef] [PubMed]

95. Schmal, H.; Czermak, B.J.; Lentsch, A.B.; Bless, N.M.; Beck-Schimmer, B.; Friedl, H.P.; Ward, P.A. Soluble icam-1 activates lung macrophages and enhances lung injury. J. Immunol. 1998, 161, 3685-3693.

96. Lawson, C.; Wolf, S. Icam-1 signaling in endothelial cells. Pharmacol. Rep. 2009, 61, 22-32. [CrossRef]

97. Peter, K.; Nawroth, P.; Conradt, C.; Nordt, T.; Weiss, T.; Boehme, M.; Wunsch, A.; Allenberg, J.; Kubler, W.; Bode, C. Circulating vascular cell adhesion molecule- 1 correlates with the extent of human atherosclerosis in contrast to circulating intercellular adhesion molecule-1, e-selectin, p-selectin, and thrombomodulin. Arterioscler. Thromb. Vasc. Biol. 1997, 17, 505-512. [CrossRef]

98. De Caterina, R.; Basta, G.; Lazzerini, G.; Dell'Omo, G.; Petrucci, R.; Morale, M.; Carmassi, F.; Pedrinelli, R. Soluble vascular cell adhesion molecule-1 as a biohumoral correlate of atherosclerosis. Arterioscler. Thromb. Vasc. Biol. 1997, 17, 2646-2654. [CrossRef]

99. Ridker, P.M. Intercellular adhesion molecule (icam-1) and the risks of developing atherosclerotic disease. Eur. Heart J. 1998, 19, 1119-1121.

100. Dimopoulos, N.; Piperi, C.; Salonicioti, A.; Mitsonis, C.; Liappas, I.; Lea, R.W.; Kalofoutis, A. Elevation of plasma concentration of adhesion molecules in late-life depression. Int. J. Geriatr. Psychiatry 2006, 21, 965-971. [CrossRef]

101. Van Sloten, T.T.; Schram, M.T.; Adriaanse, M.C.; Dekker, J.M.; Nijpels, G.; Teerlink, T.; Scheffer, P.G.; Pouwer, F.; Schalkwijk, C.G.; Stehouwer, C.D.; et al. Endothelial dysfunction is associated with a greater depressive symptom score in a general elderly population: The hoorn study. Psychol. Med. 2014, 44, 1403-1416. [CrossRef] [PubMed]

102. Gragnano, F.; Sperlongano, S.; Golia, E.; Natale, F.; Bianchi, R.; Crisci, M.; Fimiani, F.; Pariggiano, I.; Diana, V.; Carbone, A.; et al. The role of von willebrand factor in vascular inflammation: From pathogenesis to targeted therapy. Mediat. Inflamm. 2017, 2017, 5620314. [CrossRef] [PubMed]

103. Kovacevic, K.D.; Mayer, F.J.; Jilma, B.; Buchtele, N.; Obermayer, G.; Binder, C.J.; Blann, A.D.; Minar, E.; Schillinger, M.; Hoke, M. Von willebrand factor antigen levels predict major adverse cardiovascular events in patients with carotid stenosis of the icaras study. Atherosclerosis 2019, 290, 31-36. [CrossRef] [PubMed]

104. Bongers, T.N.; De Maat, M.P.; Van Goor, M.L.; Bhagwanbali, V.; Van Vliet, H.H.; Gomez Garcia, E.B.; Dippel, D.W.; Leebeek, F.W. High von willebrand factor levels increase the risk of first ischemic stroke: Influence of adamts13, inflammation, and genetic variability. Stroke 2006, 37, 2672-2677. [CrossRef] [PubMed]

105. Wieberdink, R.G.; Van Schie, M.C.; Koudstaal, P.J.; Hofman, A.; Witteman, J.C.; De Maat, M.P.; Leebeek, F.W.; Breteler, M.M. High von willebrand factor levels increase the risk of stroke: The rotterdam study. Stroke 2010, 41, 2151-2156. [CrossRef]

106. Kraft, P.; Drechsler, C.; Gunreben, I.; Nieswandt, B.; Stoll, G.; Heuschmann, P.U.; Kleinschnitz, C. Von willebrand factor regulation in patients with acute and chronic cerebrovascular disease: A pilot, case-control study. PLoS ONE 2014, 9, e99851. [CrossRef]

107. Thompson, S.G.; Kienast, J.; Pyke, S.D.; Haverkate, F.; Van de Loo, J.C. Hemostatic factors and the risk of myocardial infarction or sudden death in patients with angina pectoris. European concerted action on thrombosis and disabilities angina pectoris study group. N. Engl. J. Med. 1995, 332, 635-641. [CrossRef]

108. Spiel, A.O.; Gilbert, J.C.; Jilma, B. Von willebrand factor in cardiovascular disease: Focus on acute coronary syndromes. Circulation 2008, 117, 1449-1459. [CrossRef]

109. Domenici, E.; Wille, D.R.; Tozzi, F.; Prokopenko, I.; Miller, S.; McKeown, A.; Brittain, C.; Rujescu, D.; Giegling, I.; Turck, C.W.; et al. Plasma protein biomarkers for depression and schizophrenia by multi analyte profiling of case-control collections. PLoS ONE 2010, 5, e9166. [CrossRef]

110. Bot, M.; Chan, M.K.; Jansen, R.; Lamers, F.; Vogelzangs, N.; Steiner, J.; Leweke, F.M.; Rothermundt, M.; Cooper, J.; Bahn, S.; et al. Serum proteomic profiling of major depressive disorder. Transl. Psychiatry 2015, 5, e599. [CrossRef]

111. Lopez-Vilchez, I.; Diaz-Ricart, M.; Navarro, V.; Torramade, S.; Zamorano-Leon, J.; Lopez-Farre, A.; Galan, A.M.; Gasto, C.; Escolar, G. Endothelial damage in major depression patients is modulated by ssri treatment, as demonstrated by circulating biomarkers and an in vitro cell model. Transl. Psychiatry 2016, 6, e886. [CrossRef] [PubMed] 
112. Paffen, E.; DeMaat, M.P. C-reactive protein in atherosclerosis: A causal factor? Cardiovasc. Res. 2006, 71, 30-39. [CrossRef] [PubMed]

113. Singh, S.K.; Suresh, M.V.; Voleti, B.; Agrawal, A. The connection between c-reactive protein and atherosclerosis. Ann. Med. 2008, 40, 110-120. [CrossRef] [PubMed]

114. Badimon, L.; Pena, E.; Arderiu, G.; Padro, T.; Slevin, M.; Vilahur, G.; Chiva-Blanch, G. C-reactive protein in atherothrombosis and angiogenesis. Front. Immunol. 2018, 9, 430. [CrossRef] [PubMed]

115. Ridker, P.M.; Rifai, N.; Stampfer, M.J.; Hennekens, C.H. Plasma concentration of interleukin-6 and the risk of future myocardial infarction among apparently healthy men. Circulation 2000, 101, 1767-1772. [CrossRef] [PubMed]

116. Osimo, E.F.; Baxter, L.J.; Lewis, G.; Jones, P.B.; Khandaker, G.M. Prevalence of low-grade inflammation in depression: A systematic review and meta-analysis of crp levels. Psychol. Med. 2019, 49, 1958-1970. [CrossRef] [PubMed]

117. Chamberlain, S.R.; Cavanagh, J.; De Boer, P.; Mondelli, V.; Jones, D.N.C.; Drevets, W.C.; Cowen, P.J.; Harrison, N.A.; Pointon, L.; Pariante, C.M.; et al. Treatment-resistant depression and peripheral c-reactive protein. Br. J. Psychiatry 2019, 214, 11-19. [CrossRef]

118. Felger, J.C.; Haroon, E.; Patel, T.A.; Goldsmith, D.R.; Wommack, E.C.; Woolwine, B.J.; Le, N.A.; Feinberg, R.; Tansey, M.G.; Miller, A.H. What does plasma crp tell us about peripheral and central inflammation in depression? Mol. Psychiatry 2018. [CrossRef]

119. De Berardis, D.; Campanella, D.; Gambi, F.; La Rovere, R.; Carano, A.; Conti, C.M.; Sivestrini, C.; Serroni, N.; Piersanti, D.; Di Giuseppe, B.; et al. The role of c-reactive protein in mood disorders. Int. J. Immunopathol. Pharmacol. 2006, 19, 721-725. [CrossRef]

120. De Berardis, D.; Fornaro, M.; Orsolini, L.; Iasevoli, F.; Tomasetti, C.; De Bartolomeis, A.; Serroni, N.; De Lauretis, I.; Girinelli, G.; Mazza, M.; et al. Effect of agomelatine treatment on c-reactive protein levels in patients with major depressive disorder: An exploratory study in "real-world", everyday clinical practice. CNS Spectr. 2017, 22, 342-347. [CrossRef]

121. Erzen, B.; Sabovic, M.; Sebestjen, M.; Keber, I.; Poredos, P. Interleukin-6 correlates with endothelial dysfunction in young post-myocardial infarction patients. Cardiology 2007, 107, 111-116. [CrossRef] [PubMed]

122. Hartman, J.; Frishman, W.H. Inflammation and atherosclerosis: A review of the role of interleukin-6 in the development of atherosclerosis and the potential for targeted drug therapy. Cardiol. Rev. 2014, 22, 147-151. [CrossRef] [PubMed]

123. Howren, M.B.; Lamkin, D.M.; Suls, J. Associations of depression with c-reactive protein, il-1, and il-6: A meta-analysis. Psychosom. Med. 2009, 71, 171-186. [CrossRef] [PubMed]

124. Haapakoski, R.; Mathieu, J.; Ebmeier, K.P.; Alenius, H.; Kivimaki, M. Cumulative meta-analysis of interleukins 6 and 1 beta, tumour necrosis factor alpha and c-reactive protein in patients with major depressive disorder. Brain. Behav. Immun. 2015, 49, 206-215. [CrossRef]

125. Bruunsgaard, H.; Skinhoj, P.; Pedersen, A.N.; Schroll, M.; Pedersen, B.K. Ageing, tumour necrosis factor-alpha (tnf-alpha) and atherosclerosis. Clin. Exp. Immunol. 2000, 121, 255-260. [CrossRef]

126. Dowlati, Y.; Herrmann, N.; Swardfager, W.; Liu, H.; Sham, L.; Reim, E.K.; Lanctot, K.L. A meta-analysis of cytokines in major depression. Biol. Psychiatry 2010, 67, 446-457. [CrossRef]

127. Liu, Y.; Ho, R.C.; Mak, A. Interleukin (il)-6, tumour necrosis factor alpha (tnf-alpha) and soluble interleukin-2 receptors (sil-2r) are elevated in patients with major depressive disorder: A meta-analysis and meta-regression. J. Affect. Disord. 2012, 139, 230-239. [CrossRef]

128. Lesperance, F.; Frasure-Smith, N.; Theroux, P.; Irwin, M. The association between major depression and levels of soluble intercellular adhesion molecule 1, interleukin-6, and c-reactive protein in patients with recent acute coronary syndromes. Am. J. Psychiatry 2004, 161, 271-277. [CrossRef]

129. Tchalla, A.E.; Wellenius, G.A.; Sorond, F.A.; Travison, T.G.; Dantoine, T.; Lipsitz, L.A. Elevated circulating vascular cell adhesion molecule-1 (svcam-1) is associated with concurrent depressive symptoms and cerebral white matter hyperintensities in older adults. BMC Geriatr. 2015, 15, 62. [CrossRef]

130. Muller, N. The role of intercellular adhesion molecule-1 in the pathogenesis of psychiatric disorders. Front. Pharmacol. 2019, 10, 1251. [CrossRef]

131. Hillaert, M.A.; Lentjes, E.G.; Beygui, F.; Kemperman, H.; Asselbergs, F.W.; Nathoe, H.M.; Agostoni, P.; Voskuil, M.; Ivanes, F.; Jude, B.; et al. Measuring and targeting aldosterone and renin in atherosclerosis-a review of clinical data. Am. Heart. J. 2011, 162, 585-596. [CrossRef] [PubMed] 
132. Zehr, K.R.; Walker, M.K. Omega-3 polyunsaturated fatty acids improve endothelial function in humans at risk for atherosclerosis: A review. Prostaglandins Other Lipid Mediat. 2018, 134, 131-140. [CrossRef]

133. Calder, P.C. Marine omega-3 fatty acids and inflammatory processes: Effects, mechanisms and clinical relevance. Biochim. Biophys. Acta 2015, 1851, 469-484. [CrossRef] [PubMed]

134. Schunck, W.H.; Konkel, A.; Fischer, R.; Weylandt, K.H. Therapeutic potential of omega-3 fatty acid-derived epoxyeicosanoids in cardiovascular and inflammatory diseases. Pharmacol. Ther. 2018, 183, 177-204. [CrossRef] [PubMed]

135. Arterburn, L.M.; Hall, E.B.; Oken, H. Distribution, interconversion, and dose response of $n-3$ fatty acids in humans. Am. J. Clin. Nutr. 2006, 83, 1467S-1476S. [CrossRef] [PubMed]

136. Bazinet, R.P.; Laye, S. Polyunsaturated fatty acids and their metabolites in brain function and disease. Nat. Rev. Neurosci. 2014, 15, 771-785. [CrossRef] [PubMed]

137. Dyall, S.C. Long-chain omega-3 fatty acids and the brain: A review of the independent and shared effects of epa, dpa and dha. Front. Aging Neurosci. 2015, 7, 52. [CrossRef]

138. Chen, C.T.; Domenichiello, A.F.; Trepanier, M.O.; Liu, Z.; Masoodi, M.; Bazinet, R.P. The low levels of eicosapentaenoic acid in rat brain phospholipids are maintained via multiple redundant mechanisms. J. Lipid Res. 2013, 54, 2410-2422. [CrossRef]

139. Mozaffarian, D.; Lemaitre, R.N.; King, I.B.; Song, X.; Spiegelman, D.; Sacks, F.M.; Rimm, E.B.; Siscovick, D.S. Circulating long-chain omega-3 fatty acids and incidence of congestive heart failure in older adults: The cardiovascular health study: A cohort study. Ann. Intern. Med. 2011, 155, 160-170. [CrossRef]

140. Steffen, B.T.; Steffen, L.M.; Tracy, R.; Siscovick, D.; Hanson, N.Q.; Nettleton, J.; Tsai, M.Y. Obesity modifies the association between plasma phospholipid polyunsaturated fatty acids and markers of inflammation: The multi-ethnic study of atherosclerosis. Int. J. Obes. (Lond.) 2012, 36, 797-804. [CrossRef]

141. Yang, Y.; Lu, N.; Chen, D.; Meng, L.; Zheng, Y.; Hui, R. Effects of n-3 pufa supplementation on plasma soluble adhesion molecules: A meta-analysis of randomized controlled trials. Am. J. Clin. Nutr. 2012, 95, 972-980. [CrossRef] [PubMed]

142. Fleming, J.A.; Kris-Etherton, P.M. The evidence for alpha-linolenic acid and cardiovascular disease benefits: Comparisons with eicosapentaenoic acid and docosahexaenoic acid. Adv. Nutr. 2014, 5, 863S-876S. [CrossRef] [PubMed]

143. Martins, J.G. Epa but not dha appears to be responsible for the efficacy of omega-3 long chain polyunsaturated fatty acid supplementation in depression: Evidence from a meta-analysis of randomized controlled trials. J. Am. Coll. Nutr. 2009, 28, 525-542. [CrossRef] [PubMed]

144. Sublette, M.E.; Ellis, S.P.; Geant, A.L.; Mann, J.J. Meta-analysis of the effects of eicosapentaenoic acid (epa) in clinical trials in depression. J. Clin. Psychiatry 2011, 72, 1577-1584. [CrossRef] [PubMed]

145. Grosso, G.; Pajak, A.; Marventano, S.; Castellano, S.; Galvano, F.; Bucolo, C.; Drago, F.; Caraci, F. Role of omega-3 fatty acids in the treatment of depressive disorders: A comprehensive meta-analysis of randomized clinical trials. PLoS ONE 2014, 9, e96905. [CrossRef] [PubMed]

146. Mocking, R.J.; Harmsen, I.; Assies, J.; Koeter, M.W.; Ruhe, H.G.; Schene, A.H. Meta-analysis and meta-regression of omega-3 polyunsaturated fatty acid supplementation for major depressive disorder. Transl. Psychiatry 2016, 6, e756. [CrossRef]

147. Marangell, L.B.; Martinez, J.M.; Zboyan, H.A.; Kertz, B.; Kim, H.F.; Puryear, L.J. A double-blind, placebo-controlled study of the omega-3 fatty acid docosahexaenoic acid in the treatment of major depression. Am. J. Psychiatry 2003, 160, 996-998. [CrossRef]

148. Yang, B.; Lin, L.; Bazinet, R.P.; Chien, Y.C.; Chang, J.P.; Satyanarayanan, S.K.; Su, H.; Su, K.P. Clinical efficacy and biological regulations of omega-3 pufa-derived endocannabinoids in major depressive disorder. Psychother. Psychosom. 2019, 88, 215-224. [CrossRef]

149. Artmann, A.; Petersen, G.; Hellgren, L.I.; Boberg, J.; Skonberg, C.; Nellemann, C.; Hansen, S.H.; Hansen, H.S. Influence of dietary fatty acids on endocannabinoid and n-acylethanolamine levels in rat brain, liver and small intestine. Biochim. Biophys. Acta 2008, 1781, 200-212. [CrossRef]

150. Steffens, S.; Pacher, P. The activated endocannabinoid system in atherosclerosis: Driving force or protective mechanism? Curr. Drug Targets 2015, 16, 334-341. [CrossRef]

151. Hind, W.H.; Tufarelli, C.; Neophytou, M.; Anderson, S.I.; England, T.J.; O'Sullivan, S.E. Endocannabinoids modulate human blood-brain barrier permeability in vitro. Br. J. Pharmacol. 2015, 172, 3015-3027. [CrossRef] [PubMed] 
152. Benyo, Z.; Ruisanchez, E.; Leszl-Ishiguro, M.; Sandor, P.; Pacher, P. Endocannabinoids in cerebrovascular regulation. Am. J. Physiol. Heart. Circ. Physiol. 2016, 310, H785-H801. [CrossRef] [PubMed]

153. Chiurchiu, V.; Battistini, L.; Maccarrone, M. Endocannabinoid signalling in innate and adaptive immunity. Immunology 2015, 144, 352-364. [CrossRef] [PubMed]

154. Chiurchiu, V.; Leuti, A.; Maccarrone, M. Bioactive lipids and chronic inflammation: Managing the fire within. Front. Immunol. 2018, 9, 38. [CrossRef]

155. Smaga, I.; Bystrowska, B.; Gawlinski, D.; Przegalinski, E.; Filip, M. The endocannabinoid/endovanilloid system and depression. Curr. Neuropharmacol. 2014, 12, 462-474. [CrossRef]

156. Balvers, M.G.; Verhoeckx, K.C.; Plastina, P.; Wortelboer, H.M.; Meijerink, J.; Witkamp, R.F. Docosahexaenoic acid and eicosapentaenoic acid are converted by 3t3-11 adipocytes to n-acyl ethanolamines with anti-inflammatory properties. Biochim. Biophys. Acta 2010, 1801, 1107-1114. [CrossRef]

157. Meijerink, J.; Balvers, M.; Witkamp, R. N-acyl amines of docosahexaenoic acid and other n-3 polyunsatured fatty acids-From fishy endocannabinoids to potential leads. Br. J. Pharmacol. 2013, 169, 772-783. [CrossRef]

158. Rouzer, C.A.; Marnett, L.J. Endocannabinoid oxygenation by cyclooxygenases, lipoxygenases, and cytochromes p450: Cross-talk between the eicosanoid and endocannabinoid signaling pathways. Chem. Rev. 2011, 111, 5899-5921. [CrossRef]

159. Fleming, I. The pharmacology of the cytochrome p450 epoxygenase/soluble epoxide hydrolase axis in the vasculature and cardiovascular disease. Pharmacol. Rev. 2014, 66, 1106-1140. [CrossRef]

160. McDougle, D.R.; Watson, J.E.; Abdeen, A.A.; Adili, R.; Caputo, M.P.; Krapf, J.E.; Johnson, R.W.; Kilian, K.A.; Holinstat, M.; Das, A. Anti-inflammatory omega-3 endocannabinoid epoxides. Proc. Natl. Acad. Sci. USA 2017, 114, E6034-E6043. [CrossRef]

161. Jung, F.; Schulz, C.; Blaschke, F.; Muller, D.N.; Mrowietz, C.; Franke, R.P.; Lendlein, A.; Schunck, W.H. Effect of cytochrome p450-dependent epoxyeicosanoids on ristocetin-induced thrombocyte aggregation. Clin. Hemorheol. Microcirc. 2012, 52, 403-416. [CrossRef] [PubMed]

162. Rajesh, M.; Mukhopadhyay, P.; Batkai, S.; Hasko, G.; Liaudet, L.; Huffman, J.W.; Csiszar, A.; Ungvari, Z.; Mackie, K.; Chatterjee, S.; et al. Cb2-receptor stimulation attenuates tnf-alpha-induced human endothelial cell activation, transendothelial migration of monocytes, and monocyte-endothelial adhesion. Am. J. Physiol. Heart. Circ. Physiol. 2007, 293, H2210-H2218. [CrossRef] [PubMed]

163. Zhao, Y.; Yuan, Z.; Liu, Y.; Xue, J.; Tian, Y.; Liu, W.; Zhang, W.; Shen, Y.; Xu, W.; Liang, X.; et al. Activation of cannabinoid $\mathrm{cb} 2$ receptor ameliorates atherosclerosis associated with suppression of adhesion molecules. J. Cardiovasc. Pharmacol. 2010, 55, 292-298. [CrossRef]

164. Ramirez, S.H.; Hasko, J.; Skuba, A.; Fan, S.; Dykstra, H.; McCormick, R.; Reichenbach, N.; Krizbai, I.; Mahadevan, A.; Zhang, M.; et al. Activation of cannabinoid receptor 2 attenuates leukocyte-endothelial cell interactions and blood-brain barrier dysfunction under inflammatory conditions. J. Neurosci. 2012, 32, 4004-4016. [CrossRef] [PubMed]

165. Persidsky, Y.; Fan, S.; Dykstra, H.; Reichenbach, N.L.; Rom, S.; Ramirez, S.H. Activation of cannabinoid type two receptors (cb2) diminish inflammatory responses in macrophages and brain endothelium. J. Neuroimmune Pharmacol. 2015, 10, 302-308. [CrossRef] [PubMed]

166. Rush, A.J.; Sackeim, H.A.; Marangell, L.B.; George, M.S.; Brannan, S.K.; Davis, S.M.; Lavori, P.; Howland, R.; Kling, M.A.; Rittberg, B.; et al. Effects of 12 months of vagus nerve stimulation in treatment-resistant depression: A naturalistic study. Biol. Psychiatry 2005, 58, 355-363. [CrossRef]

167. Bajbouj, M.; Merkl, A.; Schlaepfer, T.E.; Frick, C.; Zobel, A.; Maier, W.; O’Keane, V.; Corcoran, C.; Adolfsson, R.; Trimble, M.; et al. Two-year outcome of vagus nerve stimulation in treatment-resistant depression. J. Clin. Psychopharmacol. 2010, 30, 273-281. [CrossRef]

168. Kraus, C.; Kadriu, B.; Lanzenberger, R.; Zarate, C.A., Jr.; Kasper, S. Prognosis and improved outcomes in major depression: A review. Transl. Psychiatry 2019, 9, 127. [CrossRef]

169. Wang, H.; Yu, M.; Ochani, M.; Amella, C.A.; Tanovic, M.; Susarla, S.; Li, J.H.; Wang, H.; Yang, H.; Ulloa, L.; et al. Nicotinic acetylcholine receptor alpha7 subunit is an essential regulator of inflammation. Nature 2003, 421, 384-388. [CrossRef]

170. Tracey, K.J. Reflex control of immunity. Nat. Rev. Immunol. 2009, 9, 418-428. [CrossRef]

171. Howland, R.H. Vagus nerve stimulation. Curr. Behav. Neurosci. Rep. 2014, 1, 64-73. [CrossRef] [PubMed] 
172. Saeed, R.W.; Varma, S.; Peng-Nemeroff, T.; Sherry, B.; Balakhaneh, D.; Huston, J.; Tracey, K.J.; Al-Abed, Y.; Metz, C.N. Cholinergic stimulation blocks endothelial cell activation and leukocyte recruitment during inflammation. J. Exp. Med. 2005, 201, 1113-1123. [CrossRef]

173. Cooke, J.P.; Ghebremariam, Y.T. Endothelial nicotinic acetylcholine receptors and angiogenesis. Trends Cardiovasc. Med. 2008, 18, 247-253. [CrossRef] [PubMed]

174. De Jonge, W.J.; Van der Zanden, E.P.; The, F.O.; Bijlsma, M.F.; Van Westerloo, D.J.; Bennink, R.J.; Berthoud, H.R.; Uematsu, S.; Akira, S.; Van den Wijngaard, R.M.; et al. Stimulation of the vagus nerve attenuates macrophage activation by activating the jak2-stat3 signaling pathway. Nat. Immunol. 2005, 6, 844-851. [CrossRef] [PubMed]

175. Hashimoto, T.; Ichiki, T.; Watanabe, A.; Hurt-Camejo, E.; Michaelsson, E.; Ikeda, J.; Inoue, E.; Matsuura, H.; Tokunou, T.; Kitamoto, S.; et al. Stimulation of alpha7 nicotinic acetylcholine receptor by ar-r17779 suppresses atherosclerosis and aortic aneurysm formation in apolipoprotein e-deficient mice. Vascul. Pharmacol. 2014, 61, 49-55. [CrossRef] [PubMed]

176. Marrero, M.B.; Lucas, R.; Salet, C.; Hauser, T.A.; Mazurov, A.; Lippiello, P.M.; Bencherif, M. An alpha7 nicotinic acetylcholine receptor-selective agonist reduces weight gain and metabolic changes in a mouse model of diabetes. J. Pharmacol. Exp. Ther. 2010, 332, 173-180. [CrossRef] [PubMed]

177. Hasan, M.K.; Friedman, T.C.; Sims, C.; Lee, D.L.; Espinoza-Derout, J.; Ume, A.; Chalfant, V.; Lee, M.L.; Sinha-Hikim, I.; Lutfy, K.; et al. Alpha7-nicotinic acetylcholine receptor agonist ameliorates nicotine plus high-fat diet-induced hepatic steatosis in male mice by inhibiting oxidative stress and stimulating ampk signaling. Endocrinology 2018, 159, 931-944. [CrossRef]

178. Mazloom, R.; Eftekhari, G.; Rahimi-Balaei, M.; Khori, V.; Hajizadeh, S.; Dehpour, A.R.; Mani, A.R. Correction: The role of alpha7 nicotinic acetylcholine receptor in modulation of heart rate dynamics in endotoxemic rats. PLoS ONE 2015, 10, e0127826. [CrossRef]

179. Tabas, I. Macrophage death and defective inflammation resolution in atherosclerosis. Nat. Rev. Immunol. 2010, 10, 36-46. [CrossRef]

180. Aoyama, M.; Kotani, J.; Usami, M. Butyrate and propionate induced activated or non-activated neutrophil apoptosis via hdac inhibitor activity but without activating gpr-41/gpr-43 pathways. Nutrition 2010, 26, 653-661. [CrossRef]

181. Montero-Melendez, T.; Dalli, J.; Perretti, M. Gene expression signature-based approach identifies a pro-resolving mechanism of action for histone deacetylase inhibitors. Cell Death Differ. 2013, 20, 567-575. [CrossRef] [PubMed]

182. Soliman, G.A. Dietary fiber, atherosclerosis, and cardiovascular disease. Nutrients 2019, 11, 1155. [CrossRef] [PubMed]

183. Bowes, A.J.; Khan, M.I.; Shi, Y.; Robertson, L.; Werstuck, G.H. Valproate attenuates accelerated atherosclerosis in hyperglycemic apoe-deficient mice: Evidence in support of a role for endoplasmic reticulum stress and glycogen synthase kinase-3 in lesion development and hepatic steatosis. Am. J. Pathol. 2009, 174, 330-342. [CrossRef]

184. Huang, A.; Young, T.L.; Dang, V.T.; Shi, Y.; McAlpine, C.S.; Werstuck, G.H. 4-phenylbutyrate and valproate treatment attenuates the progression of atherosclerosis and stabilizes existing plaques. Atherosclerosis 2017, 266, 103-112. [CrossRef] [PubMed]

185. Kim, H.J.; Rowe, M.; Ren, M.; Hong, J.S.; Chen, P.S.; Chuang, D.M. Histone deacetylase inhibitors exhibit anti-inflammatory and neuroprotective effects in a rat permanent ischemic model of stroke: Multiple mechanisms of action. J. Pharmacol. Exp. Ther. 2007, 321, 892-901. [CrossRef]

186. Leus, N.G.; Zwinderman, M.R.; Dekker, F.J. Histone deacetylase 3 (hdac 3) as emerging drug target in nf-kappab-mediated inflammation. Curr. Opin. Chem. Biol. 2016, 33, 160-168. [CrossRef]

187. Olesen, J.B.; Abildstrom, S.Z.; Erdal, J.; Gislason, G.H.; Weeke, P.; Andersson, C.; Torp-Pedersen, C.; Hansen, P.R. Effects of epilepsy and selected antiepileptic drugs on risk of myocardial infarction, stroke, and death in patients with or without previous stroke: A nationwide cohort study. Pharmacoepidemiol. Drug Saf. 2011, 20, 964-971. [CrossRef]

188. Brookes, R.L.; Crichton, S.; Wolfe, C.D.A.; Yi, Q.; Li, L.; Hankey, G.J.; Rothwell, P.M.; Markus, H.S. Sodium valproate, a histone deacetylase inhibitor, is associated with reduced stroke risk after previous ischemic stroke or transient ischemic attack. Stroke 2018, 49, 54-61. [CrossRef] 
189. Olesen, J.B.; Hansen, P.R.; Abildstrom, S.Z.; Andersson, C.; Weeke, P.; Schmiegelow, M.; Erdal, J.; Torp-Pedersen, C.; Gislason, G.H. Valproate attenuates the risk of myocardial infarction in patients with epilepsy: A nationwide cohort study. Pharmacoepidemiol. Drug Saf. 2011, 20, 146-153. [CrossRef]

190. Davis, L.L.; Kabel, D.; Patel, D.; Choate, A.D.; Foslien-Nash, C.; Gurguis, G.N.; Kramer, G.L.; Petty, F. Valproate as an antidepressant in major depressive disorder. Psychopharmacol. Bull. 1996, 32, 647-652.

191. Bowden, C.L. Valproate. Bipolar. Disord. 2003, 5, 189-202. [CrossRef] [PubMed]

192. Smith, L.A.; Cornelius, V.R.; Azorin, J.M.; Perugi, G.; Vieta, E.; Young, A.H.; Bowden, C.L. Valproate for the treatment of acute bipolar depression: Systematic review and meta-analysis. J. Affect. Disord. 2010, 122, 1-9. [CrossRef] [PubMed]

193. Raison, C.L.; Miller, A.H. Is depression an inflammatory disorder? Curr. Psychiatry Rep. 2011, 13, 467-475. [CrossRef] [PubMed]

194. Krishnadas, R.; Cavanagh, J. Depression: An inflammatory illness? J. Neurol. Neurosurg. Psychiatry 2012, 83, 495-502. [CrossRef]

195. Lanquillon, S.; Krieg, J.C.; Bening-Abu-Shach, U.; Vedder, H. Cytokine production and treatment response in major depressive disorder. Neuropsychopharmacology 2000, 22, 370-379. [CrossRef]

196. O’Brien, S.M.; Scully, P.; Fitzgerald, P.; Scott, L.V.; Dinan, T.G. Plasma cytokine profiles in depressed patients who fail to respond to selective serotonin reuptake inhibitor therapy. J. Psychiatr. Res. 2007, 41, 326-331. [CrossRef]

197. Tulner, D.M.; Smith, O.R.; Schins, A.; De Jonge, P.; Quere, M.; Delanghe, J.R.; Crijns, H.J.; Den Boer, J.A.; Korf, J.; Honig, A. Antidepressive effect of mirtazapine in post-myocardial infarction depression is associated with soluble tnf-r1 increase: Data from the mind-it. Neuropsychobiology 2011, 63, 169-176. [CrossRef]

198. Kopschina Feltes, P.; Doorduin, J.; Klein, H.C.; Juarez-Orozco, L.E.; Dierckx, R.A.; Moriguchi-Jeckel, C.M.; De Vries, E.F. Anti-inflammatory treatment for major depressive disorder: Implications for patients with an elevated immune profile and non-responders to standard antidepressant therapy. J. Psychopharmacol. 2017, 31, 1149-1165. [CrossRef]

199. Rapaport, M.H.; Nierenberg, A.A.; Schettler, P.J.; Kinkead, B.; Cardoos, A.; Walker, R.; Mischoulon, D. Inflammation as a predictive biomarker for response to omega-3 fatty acids in major depressive disorder: A proof-of-concept study. Mol. Psychiatry 2016, 21, 71-79. [CrossRef]

(C) 2020 by the author. Licensee MDPI, Basel, Switzerland. This article is an open access article distributed under the terms and conditions of the Creative Commons Attribution (CC BY) license (http://creativecommons.org/licenses/by/4.0/). 